\title{
The pedagogy of martyrdom among female suicide bombers
}

\begin{abstract}
The controversial and timely subject of suicide operations or "martyrdom operations" has received both praise and condemnation: extolled when the targets were military and censured when the targets were innocent civilians. Although suicide operations occur in many places, they seem related to national struggles, or at least, those are the cases that I have chosen to bring to the fore. The framing of the argument rests on the understanding of martyrdom in relation to dignity, honor, and symbolic capital. The gender aspect is highlighted because my interest is in understanding the mindset of female suicide bombers in relation to their male counterparts when it comes to national and liberation struggle. This article gives an overview of women who engage in suicide operations in combat (targeting soldiers) and noncombat (targeting civilians) situations, mainly in Lebanon and the Middle East, but refers heuristically to the Far East for the sake of enlightening comparisons. For instance, while the Lebanese Hizbullah conducted twelve suicide operations by Shi'a males and eight female Palestinian suicide bombers (including mothers) followed suit in Israel, secular Lebanese political parties have conducted suicide operations by both genders targeting Israeli occupation forces. The PKK in Turkey targeted both military and civilian targets. In the Far East, female suicide operations for the struggle for national independence were conducted by the LTTE in Sri Lanka and India and BKI in India. While ethnographic research was done in Lebanon, I relied on discourse analysis of relevant sources (in other area studies) to comprehend similar phenomena elsewhere. My finding is that the pedagogy of martyrdom seems to rests on two main points:
\end{abstract}

I. Symbolic and religious capital (honor, dignity, nationalism)

II. Agency: empowerment in selecting the time and place to defy and face a superior enemy, thus attempting to balance the lack of capabilities.

Keywords: self sacrifice, national resistance, suicide, martyrdom, women, female suicide bombers, kamikaze, honor, dignity, symbolic capital
Volume I Issue 2 - 2017

\author{
Joseph Alagha \\ Department of Political Science, Haigazian University, Lebanon
}

Correspondence: Joseph Alagha, Department of Political Science, Haigazian University, Lebanon, Email jalagha200।@yahoo.com, joseph.alagha@haigazian.edu.lb

Received: April 29, 2017 | Published: August 02, 2017
Abbreviations: BKI, babbar khalsa international; IDF, israeli defense forces; ISIS, islamic state in syria and iraq; LCP, lebanese communist party; LTTE, liberation tigers of tamil eelam; PKK, kurdistan workers' party; SSNP, syrian social nationalist party

\section{Introduction}

\section{Suicide operations and symbolic capital}

The cross-cultural phenomenon of martyrdom is more than two millennia old, but, as recent events continue to demonstrate, it is still a prominent feature of contemporary culture. Whether one admires or abhors martyrs, martyrdom appeals to the imagination of many, because it is a spectacle, albeit with deadly consequences. Martyrdom is also a complex power game, which is already apparent from the agonistic vocabulary in several martyrdoms. Statements about martyrs in these writings suggest that the martyrs' violent deaths imply that their opponent is defeated by them. Whether such a triumph should be interpreted in a moral, spiritual, salvation-historical or political perspective or all of these- its impact is more than a temporary reversal of the power relations at hand. Moreover, the heroic death of the martyrs remains powerful as long as it is commemorated by certain media, writings, artifacts, monuments, internet, film [social media] or even re-enacted during community meetings and ritual it expresses at the same time that the martyrs' act exemplifies the collective identity of their group. ${ }^{1}$
This article discusses nationalistic suicide operations; "martyrdom"; or self-sacrifice operations conducted by young girls and women in the Middle and Far East, but mainly concentrates on Lebanon as a case study. While the Lebanese Hizbullah conducted twelve martyrdom operations by Shi' ite males against Israeli soldiers; in Israel, many Palestinian males and eight female suicide bombers targeted both soldiers and civilians. Although martyrdom has become the trademark of radical Islamist groups, it was not solely carried out by them. For instance, secular Lebanese political parties have conducted suicide operations targeting Israeli occupation forces. The 'Lebanese Communist Party' (LCP) conducted a martyrdom operation carried out by a Christian female, while the 'Syrian Social Nationalist Party' (SSNP) has conducted twelve martyrdom operations evenly divided between six women and six men belonging to different confessions and religious denominations. Moreover, a substantial number of female suicide bombers, including girls, hailed from the Kurdistan Workers' Party (PKK) in Turkey - who are fighting for the establishment of a free, united, and independent Kurdistan - as well as the Liberation Tigers of Tamil Eelam (LTTE) in Sri Lanka and India who were struggling to found the Tamil nation.

Based on empirical and theoretical research considerations, I suggest that the common definition of martyrdom among Muslims and non-Muslims, devout and secular, is that it seems to be regarded as a form of altruistic or self-sacrificial behavior. I propose that, for Muslims, it is based mainly on the Qur'anic interpretation of symbolic 
and religious capital; for non-Muslims, the nationalistic dimension of symbolic capital seems to be the most salient. The martyr acts as anti-Destin, a bronze hawk, a hard-core altruist, in which altruism is a supererogatory act, i.e. an act done beyond the call of moral duty or obligation. Bourdieu defined symbolic capital as the "degree of accumulated prestige, celebrity, consecration or honour [dignity, possessed by someone and] founded on the dialectic of knowledge and recognition". 2,3 "Symbolic capital refers here to the status of a fighter for the cause of 'true Islam' whatever that means. The Koranic verse [4:95], which states that 'God hath granted a grade higher to those who strive and fight with their goods and persons' conveys this idea of symbolic capital. The more one fights with one's 'goods' or 'one's' 'person', the more one accumulates symbolic capital". ${ }^{4}$ However, symbolic capital is not only confined to those who fight under the banner of Islam; it is also employed by ethno-nationalist and other resistance movements. For instance, the Syrian Social Nationalist Party (SSNP) leader said in justifying resistance and martyrdom: "Life is only a stance embodied in pride and dignity." Dignity is defined as "the opposite of humiliation" at the hands of the enemy; and "death is preferable to humiliation." Hizbullah and the Palestinian Islamists employ the same discourse of 'dignity,' or symbolic capital in order to justify martyrdom operations against the Israeli occupying army, so do the relatives of martyrs when they endeavor to offer a rationale and justification for suicide operations. This also has to do with their conception of religious capital. According to Bourdieu, religious capital refers to the way religious knowledge is appropriated and disseminated. ${ }^{5,6}$ Although it is proscribed in the Qur'an to target innocent civilians, many Islamic movements have done so, most notably the notorious Islamic State in Syria and Iraq (ISIS).

\section{Discussion}

\section{Lebanon's secular and religious suicide bombers}

The spillover to the Palestinians Muslim religious scholars have unanimously vilified suicide as foolish behavior leading to perdition. They extolled and sanctioned martyrdom operations carried out in the way of God (Allah) against invading armies for the sake of liberating occupied land in wars of national resistance, whereby the martyrs blew themselves up in the enemy, intending to inflict the highest amount of possible casualties in its ranks. ${ }^{7}$

In the Middle East, the Lebanese case exemplifies both 'Islamic' and 'nationalistic martyrdom'. Compared to the Iranian and Palestinian case, Khosrokhavar classifies the Lebanese case as 'ambivalent' wavering between 'martyrdom' and 'absurd death' because of the multi-confessional, sectarian nature of the Lebanese myriad. ${ }^{8}$ Like Lewis, Khosrokhavar argues that this along with the Israeli invasions created a "prosperous ground for martyrdom". 9 Lewis rightly notes the causes behind this "culture of martyrdom" and suicide operations: If Iran's encouragement of a culture of martyrdom created the possibility for suicide attacks, the Israeli invasion created the perceived need. On an ideological level, the Israeli invasion provided an enemy against which jihad and martyrdom could be executed. Furthermore, the overwhelming disparity of force between the sides-and the seeming Israeli indifference towards civilian casualties-facilitated the emergence of suicide bombing on a practical level by necessitating armed struggle and legitimizing any effective form of attack, no matter how extreme. Other than suicide bombing, there seems to be few options that would allow small groups to project force in Lebanon, especially into fortified areas. ${ }^{10}$
Hizbullah has no women suicide bombers: Since gender is a social construction linked to role setting, Hizbullah's women did not participate in the war effort per se; rather, they contributed to it indirectly by being depicted as dedicated, good mothers and wives. This does not imply that they did not participate in the public sphere as industrious workers. On the contrary, Hizbullah accords women a prominent role in the public sphere and regards them as valuable assets who are becoming more visible in contesting the public space with other actors, and even dominating it in some professions. After all, a tangible number of the work force in Hizbullah's media institutions and a predominant number of the party's educational institutions are run by women. This explains why Hizbullah's twelve suicide operations were all conducted by males.

In the Lebanese case, Hizbullah was not the only political party that conducted "martyrdom" operations against the Israeli Defense Forces (IDF) in Lebanon. Rather, Hizbullah had fierce competition from secular multi-confessional Lebanese political parties such as the rightist SSNP, the leftist LCP, the Bath Party, and the Nasserite Social Party, especially in the years from 1985 to 1990 . While Hizbullah conducted 12 martyrdom operations by Shi'ite males, SSNP and LCP performed martyrdom operations by both males and females of different religious denominations.

SSNP Sana muhaydli: The SSNP's martyrdom operations offer a good illustration. Although Khosrokhavar' explains the 'religious motivation' behind Hizbullah's martyrdom operations, and the 'nationalistic' or 'political motivation' behind secular political parties' motivation, ${ }^{11}$ in the SSNP case, he seems to imply that, Sana Muhaydli, ${ }^{12}$ the seventeen-year-old Shi' ite SSNP girl, was the only SSNP martyr. In reality, like Hizbullah, SSNP conducted 12 martyrdom operations in total, which included, in addition to Sana, five other women. Most likely, Khosrokhavar stresses religious capital, ${ }^{9}$ but seems to be misinformed about the eleven other SSNP martyrdom operations, which in addition to Shi'ites, were carried out by Sunnis, Druz, and even Christians. The author would like to stress the nationalistic aspect and the multi-confessional nature of nationalistic identity, rather than limiting it to one sect. His hypothesis is to try proving that, for instance SSNP and LCP, non-Shi'ite martyrs sacrificed their lives, not as 'absurd deaths', but as symbolic capital in order to uphold the honor and dignity of their nation and liberate their land, as was the case with Hizbullah martyrs, for example. Concerning Muslim and secular martyrs, Khosrokhavar makes another overgeneralization by arguing that most of the martyrs come from poor, deprived classes (grassroots) of south Lebanon. ${ }^{9}$ Based on fieldwork research, the author found out that most of the martyrs originated from the middle class; some even had university education. Also, he discovered that the martyrs came from different geographical locations in Lebanon, and not predominantly from south Lebanon as Khosrokhavar asserts. In the SSNP case, the author was told that at least four martyrs had a university education and were from the middle class; one of them was even an aristocrat Christian. The SSNP martyrdom operations are based on its political ideology as stipulated by..$^{13}$ That is why, the SSNP martyrs were not only Lebanese, but included also Syrians and Palestinians. The SSNP Sana Muhaydli, 'the bride of the south', is one of the most celebrated woman martyrs; she was only 17 when she detonated herself in 1985 in an Israeli patrol..$^{10,14-17}$ When I interviewed her father Yusuf, he argued that his daughter was a martyr and that she went to heaven even though she belonged to a secular political party. As he put it, "religion is for God, and the nation is for everyone." According to Yusuf, "Sana sacrificed herself to rid Lebanon and 
Natural Syria from occupation, so that the Syrian nation can live with honor and dignity." In highlighting the nationalistic will to power of the SSNP, Sana's father quoted Saadeh: "In you is a power, which if actualized will change the course of history." He ended up by saying: "The blood that runs in our veins is not ours; rather it is the possession of our nation, when it requests it, it finds it." As such, "blood is the most extolled witnessing to life. It is a will that asks for death, when death is a road to life; it is a will expressed by our eternal martyrs." Thus, building on Saadeh, Sana's father links the concept martyrdom to the life and survival of the nation: "Our martyrs symbolize our great victories.'

LCP lola abboud: Another case in point is illustrated by the LCP upper middle class Christian, Lola Abboud, ${ }^{12,10}$ the flower of the Biqa', "a courageous woman who fought for her land and for her people, and went to her death willingly. Abboud's avowedly devout Christian family had already produced a long line of warriormartyrs". ${ }^{18}$ Lola came from the Lebanese village of al Qarun where Christians and Muslims live side by side in harmony and peaceful coexistence. According to Davis, Abboud became the "ideal martyr" for Palestinian women martyrs to emulate; "she had already paved that path in Lebanon". ${ }^{18}$ According to her brother, Ajami Fouad, ${ }^{19}$ Lola was the "family's last martyr" when she blew herself up amongst the Israeli soldiers attacking her village on April 20, 1985; she was only 19 back then. ${ }^{18}$ Fouad Abboud believes that the rationale for her martyrdom is that she was "fighting for the liberation of her own homeland," as a right and a duty and out of love for her country, in order to rupture the bitter humiliation and uphold the dignity and honor of her people. He argues that "a person is willing to die for his cause if it's a question of his very existence. All cases of martyrdom are cases of fighting for your existence. Every martyr of ours was a martyr who died in self-defense [defensive jihad]. We never went to Europe or killed Jews there. We were defending our own children". ${ }^{18}$ Dr. Abboud added: "The freedom fighter chooses death as a final choice. He doesn't choose it from the beginning. It's after he cannot fight anymore that he decides to kill himself. And she was fighting the Israelis within her own village. She was not fighting Israelis in Israel". ${ }^{18}$ Davis alludes to the notion that regards martyrdom as an altruistic behavior of a supererogatory nature. Comparing Lola to "a modern-day Joan of Arc," she writes "it's fair to say that Loula Abboud's actions exceeded all expectations not only for women in war, but for men as well". Since her martyrdom took place the day after Easter, it could be argued that her death served as a resurrection to her people. The Abboud's family patriotism was further conveyed when Dr. Abboud acknowledged that he identifies with Hizbullah and regards its leader "as a national hero". ${ }^{18}$ Davis concludes that both Lola's mother and her brother did not perceive any antagonism between Lola's "death and their strong Christian beliefs, even though Christianity, like Islam, forbids suicide". ${ }^{18}$

A Hizbullah's father's and mother's testimony on their martyred sons: Building on the notions of honor and dignity as well as the concept of symbolic capital, Munif Muhammad Ashmar offers a similar justification of martyrdom. Ashmar is a father of two Hizbullah martyrs: Ali who detonated himself in the IDF in Lebanon, and Muhammad who died in the battlefield fighting them. Before he conducted the operation on March 20, 1996, in his farewell address, Ali said, ".My body will become a fire that will burn the Israeli occupier, who everyday deliberately attempts to torture and humiliate you [the people]. However, the occupier's end is near, God willing, at the hands of the Islamic Resistance." The same rationale is offered by his father, Munif, who argues: "When duty calls and when there are dignities that are going to be downtrodden, when the pride and the honor of the ummah is going to be downtrodden by the enemy, then we will not lay idle". ${ }^{20}$ It seems that this discourse bears a striking resemblance to the SSNP slogan of "Life is only a stance embodied in pride and dignity," and that it is another indication of symbolic capital.

Likewise, a Hizbullah martyr's mother argues along similar lines stressing the importance of dignity, honor, pride, and symbolic capital in relation to self-sacrifice. On the sunny Sunday of May 9, 1999, two female Danish journalism students and the author went to interview the mother of a Hizbullah martyr whose son had detonated himself in an Israeli convey in south Lebanon. The old woman lived in the southern suburb of Beirut in a humble, barely standing home. The two students experienced a 'cultural shock' when they learned that they had to congratulate the mother instead of offering her their condolences. As a Lebanese, the author was not surprised, but the Danes were perplexed. They questioned how one could congratulate a mother on the loss of her own son. How could a caring, loving mother give her own son willingly to death? The visible astonishment of the Danes, however, was a serious challenge to the illiterate martyr's mother. She said, "My daughters, if you are bitten by a snake and the poison is flowing in your blood stream, will you let it go all the way to your heart and kill you, or will you simply suck it out?" She gave another analogy; she said that if a person discovered a cancerous gland in his body would not he remove it from the root so as not to kill him? She showed us some pictures of her son without shedding a single tear; rather, she was cool in a heeding-up manner. In particular, she argued, "Dignity is the opposite of humiliation, and death [is preferable] to humiliation". She added that the martyr (her son) "acted as an antiDestin, a bronze hawk, a hard-core altruist whose greatest duty and source of pride [honor and dignity] is to sacrifice himself for the wellbeing of his country by killing as many as possible of his enemies." She stressed, "This is the greatest pride that can befall a mother."

It seems as though the mother was reiterating - in popular culture terms - Hizbullah's conceptualization of self-sacrifice as conveyed in the party's latest document, the 2009 Manifesto. Hizbullah accords a high status to "martyrdom" and self-sacrifice, offering religious and symbolic capital justifications for it: for we are believers in righteousness; we speak in its defense and sacrifice in its quest until martyrdom. Our deeds were meant for the revival of virtue, the abolition of falsehood, the defense of your oppressed followers, the upholding of justice on your land and an appeal to your (God's) approval and nearness. For this our martyrs have died, and for this we continue to strive. You have promised us one of the two better goals or rewards (husnayayyn): either victory or the honor of encountering you through martyrdom.

In short, Hizbullah's religious ideology stresses that martyrdom is a voluntary-willed act of self-sacrifice that is religiously sanctioned, and thus diametrically opposed to suicide, which is completely prohibited in Islam, the punishment being eternal damnation in hell. In other words, Hizbullah's religious ideology regards selfsacrifice conducted on the basis of smaller military jihad as legitimate martyrdom operations, rather than suicide. However, Hizbullah clarifies that if a person blows himself up without securing a prior authorization from the religious scholars, ${ }^{7}$ then his act amounts to suicide. 
Palestinian female suicide bombers: Khosrokhavar argues that the thematic of the discourses of Lebanese martyrs, both secular and religious, are similar to the Iranian Shi'ite martyrs and Sunni Palestinian martyrs' discourses. The similarity is that all believe in the same values of combating the enemy through martyrdom, martyrdom that originates from a will to die and a desire of immortality. ${ }^{9}$ Lewis adds, Suicide bombing is by definition an organizational phenomenon. The legitimacy that makes the self-sacrifice of the individual admirable and acceptable to the community derives paradoxically from the individual's stated commitment to comrades, cause, and society, a decision that must be made free of organizational coercion. Leaders who seek to deploy suicide attackers must therefore minimize the rather significant role that they play in selecting and preparing suicide attackers to prevent themselves from being seen as cynical manipulators of human lives. Their task is made easier when a culture that devalues individual lives relative to the good of the community is firmly entrenched or when extreme need makes suicide bombing appear as a necessary force equalizer. Among Palestinian Islamists in the 1990s, the first factor was present, making the sustained use of suicide bombing possible. By the new millennium, the second factor, military need, was present as well, leading to an exceptional increase in the number of suicide attacks carried out against Israeli targets. ${ }^{18}$

In this section, I only refer to two of the eight Palestinian females who blew themselves up in the Occupied Palestinian Territories: an attorney and a mother. Then, I compare Shaykh Yasin's justification of the self-sacrifice of female suicide bombers to that of Fadlallah Ayatullah ${ }^{21} \&$ Fadlallah Hasan. ${ }^{22}$ In her study on Palestinian women suicide bombers, Barbara Victor contends that the main motive for this "fatal cocktail" is that a "culture of death" entered into the psyche of the Palestinian people as a result of hopelessness, social stress, and depression, which these relatively destitute women suffered from. ${ }^{23}$ A survey conducted by Reuter Christoph ${ }^{24}$ on the Palestinian reaction towards suicide operations conveyed that 75 percent of the Palestinians supported the October 4, 2003 suicide operation, the sixth operation conducted by a Palestinian woman since the beginning of the second Intifadah (Uprising). The operation was carried out by attorney Hanadi Jaradat who blew herself up killing twenty Israeli civilians in the wake of the celebration of Yum Kippur (Day of Forgiveness) in Haifa, a city that is supposed to portray Israeli-Palestinian peaceful coexistence. ${ }^{25}$ The sample included 1,318 Palestinians from the West Bank and Gaza, out of whom 17 percent were against the operation, and 4.4 percent vehemently condemned it. The late Shaykh Ahmad Yasin, founder of Hamas, argued, "I'm saying that in this phase (of the Uprising [Intifadah]), the participation of women is not needed, like men. We can't meet the growing demands of young men who wish to carry out martyrdom operations." On January 14, 2004, at the Erez crossing in Gaza, Reem Saleh Al-Riyashi, the seventh woman suicide bomber and the first Palestinian mother, detonated herself amongst Israeli soldiers, killing four and wounding seven. In laying Reem to rest, Mahmoud Al-Zahhar, a Hamas political leader, declared, "The martyr Reem is a heroine since she gave up everything. This was a young married woman who left behind a husband and children to go to paradise. She won't be our last." Although Shaykh Yasin earlier argued that it is not essential for women to participate in martyrdom operations, in spite of the growing number of male contenders, it seems he revoked his decision later on due to alterations dictated on the battlefield. In commenting on Al-Riyashi's operation, he said, "The operation is a watershed operation on two counts: first, because a woman executed it; second because it resulted from a joint endeavor between Kata'ib Shuhada' al-Aqsa, and Kata'ib Izzeddine AlQassam ."Yasin added that Hamas refuses any cease-fire with Israel because this is tantamount to capitulation. Yasin affirmed, "Hence, everyone knows that there is no road and no other choice save the road of resistance." In justifying women's role in jihad and martyrdom, Yasin argued that when the enemy [Israel] occupied the land of the Muslims [Palestine], jihad became a religious duty incumbent upon all Muslims, men and women. He reiterated, we used to say in the past that we leave women aside unless there is an urgent need for them to conduct martyrdom operations. Thus, when our brothers in the Kata'ib found the need to conduct an operation by resorting to a woman, they did so because, in my opinion, it is a new beginning for the woman. However, concerning jihad, it is not the beginning, rather the continuity of the path to martyrdom and struggle in the way of God by recourse to both men and women.

The late Lebanese Ayatullah Sayyid Muhammad Husayn Fadlallah $(1935$ - 2010) - the highest-ranking Shi'ite religious authority (marja ${ }^{\circ}$ ) in Lebanon - argued that a person must face power with equal or superior power. If it is legitimate to protect one's life, land, and destiny, then all means of self-defense become legitimate (1985). Fadlallah Ayatullah" ${ }^{21}$ argued that "Suicide attacks in occupied Palestine [Israel] are not the craven acts of the morally depraved as they are portrayed by Western Media, but a form of legitimate resistance amid escalating dangers." He added, "If achieving victory means that we have to go through a minefield, which necessarily and definitely means that many are going to be killed, then we would go.' Fadlallah Ayatullah ${ }^{21}$ said that the Palestinian suicide bombers aim to defend their people by inflicting damage and losses on the Israeli side to maintain a kind of equilibrium with the high-tech arsenal used by the Israeli Army". Fadlallah Ayatullah ${ }^{21}$ issued a fatwa sanctioning the martyrdom ("self-sacrifice") operations of Palestinian women, which is revolutionary because in Islam jihad is not incumbent upon women.

Fadlallah Ayatullah ${ }^{21}$ also contradicted views widely held by Islamic scholars on the role of women in jihad, saying women are allowed to participate and carry out 'self-sacrifice' operations. 'Nothing in Islam prevents women from embracing struggle and fighting for the sake of Allah. Women initially are not required to fight, for this is men's duty, but under certain circumstances [in the 'Occupied Territories'] it might be a woman's duty as well' ${ }^{26}$ There seems to be an organizational-causal link between Hizbullah and the Palestinian resistance. Conceptualizing the above narration, Lewis aptly argues, Palestinian militants decided to use suicide bombing on a regular basis in late 1993 to undermine the peace process and differentiate themselves from their rivals. They integrated their practical knowledge with the managerial techniques already developed by Joseph Alagha. ${ }^{27}$ Suicide bombing became sustainable when a significant percentage of Palestinian society came to accept it as a legitimate means of resistance and political mobilization. Leaders deliberately shifted cultural and organizational parameters to felicitate the emergence of a culture of martyrdom, which in turn facilitated the introduction of suicide bombing. It was a hybrid that resembled Hizbullah's suicide bombing in some respects and in others demonstrated considerable originality. ${ }^{10}$

Khosrokhavar Farhad ${ }^{8}$ adds: "For the Shi'ites it is God's encounter that is realized by combating an infidel enemy. For the nationalists and the communists, immortality is achieved either by identification with the 'collectivite nationale' or by identification with all the poor [deprived] in the world". ${ }^{9}$ Vroom Hendrik ${ }^{28}$ argument provides the 
seemingly missing link between sections one and two: he adds the concept of nationalistic identity construction to that of symbolic capital. He writes, the lesser jihad is armed struggle for the sake of Islam and the greater jihad the struggle against oneself - as in the gospel the one who conquers himself is stronger than the one who occupies a city. Saad Ghorayeb Amal ${ }^{29}$ [and the Palestinians] turned this around: whoever conquers himself and empties himself can come so far that he can give his life on command in an attack on the enemy. The comparison with kamikaze pilots who through Zen meditation were emptied of their selves and gave their lives for Japan is interesting. Apparently, people find the meaning for their existence in sacrificing themselves for the nation or the national religion - that is also a form of finding one's identity. ${ }^{30}$ With this smooth link, we move in the next section out of the Arab-Muslim Middle East to the Far East that is characterized by the same modus operandi (way of doing things) concerning female suicide bombers although their modus vivendi (way of life) is different.

\section{A campaign of suicide bombing: from the middle east to the far east}

Hamden Raymond ${ }^{31}$ argues that martyrdom and suicide missions are often attributed to political and religious terrorists. These regard themselves as "freedom fighters" and feel they have a responsibility to uphold the "greater good" (honor and dignity, and by extension symbolic capital) of their community since they are usually driven by ethno-geographic, nationalistic concerns. However, they have unrealistic goals and cannot be negotiated with since they are adamant in liberating the land of their forefathers and want to rule by their opaque ideological systems. ${ }^{31}$ There are 'nationalistic' types of martyrdom that have little, or, even nothing, to do with religion, but with the struggle for national independence. For example, the Chinese communists during the insurrection in Shanghai in 1927; the Japanese kamikaze $^{32}$ or Tokkotai in World War II; the Liberation Tigers of Tamil Eelam (LTTE) in Sri Lanka and India; the Kurdistan Workers' Party (PKK) in Turkey; Babbar Khalsa International (BKI) of India; and many others resorted to suicide operations. ${ }^{10,33-36}$ While the Chinese and Japanese kamikazes were men, LTTE and PKK resorted to a good number of female suicide bombers. To my knowledge, the Chinese communists are Buddhists or Confucians; the Japanese kamikazes are Shinto and Buddhists; the LTTE is mainly composed of Hindus and a few Christians; and the BKI are Sikh. Noteworthy, more than 4000 Japanese kamikazes (pilots and human torpedoes) committed suicide missions against the US forces in the Pacific: "The motivating factor in creating these special attacks units was the overwhelming disparity between the armed forces of Japan and those of the United States", ${ }^{10}$ which is the same reasoning that was used by Joseph Alagha ${ }^{27}$ and the Palestinians to justify their 'martyrdom' operations. It seems that the driving force behind the above mentioned groups is their ardent belief in ethno-nationalism, the defense of their country, or the liberation of their homeland.

"The LTTE has conducted one suicide operation in India. It is the only group to have killed two world leaders - the former prime minister of India, Rajiv Gandhi, and the president of Sri Lanka, Ranasinghe Premadasa-using male and female suicide bombers". ${ }^{33}$ The recruitment of young females could also stem from practical reasons: "the LTTE uses cute young girls that are less likely to look suspect; Palestinian Islamic Jihad often selects those who can pass for Israeli Jews" ${ }^{37}$ In short, "While the first wave of suicide attacks during the 1980s involved only five women, the LTTE and the PKK made the use of female bombers a norm during the 1990s, having incorporated them into 40 percent and 65 percent of their suicide operations, respectively". ${ }^{38}$ Between 1980 and 2000, for instance, the LTTE conducted 168 suicide operations, while the PKK conducted $22,{ }^{33}$ which is by far more than all the suicide operations conducted in Israel and Lebanon during the same period.

Noteworthy, it is estimated that at least $25 \%$ of the suicide bombers in that period were women. ${ }^{39}$ The estimates are on the rise. "Women are sacrificial lambs in places like Turkey, were women comprised 40 percent of all suicide bombers in the Kurdish Workers Party (PKK), Sri Lanka, where women exceed 25 percent of bombers in the LTTE, Chechnya, where they constitute 43 percent". ${ }^{40}$ Concerning estimates and percentages, the determination and success rates of the females seem to be higher than males: ".eleven out of the PKK's fifteen successful suicide bombings have been carried out by women". ${ }^{38}$ Although this resolve was build over decades, initially the "recruitment of young women was not on a voluntary basis. For example, the PKK's second suicide attack, which took place on October 25, 1996, was carried out by a woman named Leyla Kaplan, but she was not the first candidate considered for the mission. The first women chosen for the attack refused the mission. She was immediately executed in front of Kaplan" ${ }^{10}$ Contrary to Lewis's earlier analysis of Palestinian female suicide bombers, he stresses that " the decision to force [PKK's] women to become suicide attackers limited the power of suicide bombing to serve as a means of individual empowerment and group solidarity". ${ }^{10}$ However, recent developments seem to refute Lewis's theory revealing the voluntariness of the decision as well as women's power and empowerment of the whole community in the face of a ruthless enemy. In Kobani near Aleppo, Syria, female fighters of the People's Protection Unit (YPJ) fought to death, either by detonating or shooting themselves so as not to be defiled by the Islamic State's hardcore warriors. During the war of attrition (September 2014 January 2015) in Kobane the "well-known Kurdish fighter, Arin Mirkan, blew herself up while being surrounded by advancing ISIS fighters" ${ }^{41}$ Noteworthy, ISIS fighters believe that if they were killed by a woman, then they would be defiled, consequently denied entry to Heaven. Around 16 million Kurds are scattered among the nation states of Turkey, Iran, Iraq, and Syria. Their dream is to found, to be united in the ethno-nationalist state of Kurdistan as "the only answer to resolving their concerns and history of discrimination, abuse, and attempted genocide" by their host countries, ${ }^{10}$ as such acting as 'antidestin' or hard core altruists. ${ }^{42-48}$

While in the Palestinian case the eight female suicide bombers were volunteers, in the LTTE case they were seasoned-professional fighters who were members of the "permanently attached suicide squad called the Black Tigers, comprised of the most devoted and able volunteers selected out of the group's toughest combat units," who do not hesitate to swallow their potassium cyanide capsules in case of mission failure. ${ }^{38}$ Hamden concludes, Potential terrorist recruits typically need goals and purpose in their life; they seek a life of fairness, freedom of expression, economic security, and health. Terrorist groups can attract the recruit with financial security, while offering them the right to be heard and be treated with respect, as well as a heroic purpose for the common good of his and her people. ${ }^{31}$

\section{Conclusion}

It might be argued that the process of thought illustrated by the aforementioned exposition is that suicide operations are exploited 
by Islamist movements' and nationalist's leaders to grant symbolic or religious capital to members and supporters who get killed in a political or military battle. Martyrdom - which is extolled as a religious injunction or nationalistic duty - is used by them as an instrument of mobilization, especially when the recruits are promised the ticket to heaven or eternal rewards if they conduct self-sacrificial operations. This might explain why Islamist and nationalist movements consider martyrdom as the most extolled human sacrifice, while the international community regards it as terrorist-suicide attacks. ${ }^{4-55}$

The Islamists' argument-that there is no distinction between dying while fighting in the battlefield and blowing oneself up-seems to have shattered the commonly held theological view that regards giving one's life for the faith to die as a "martyr" as not the same thing as blowing oneself up. However, the religious-ideological justifications of self-sacrifice and martyrdom do not rule out the political practicality of forcing the enemy to withdraw from occupied land and achieve victory, since this practicality is based upon, and sanctioned by religious-ideological grounds, which regard jihad as having two glorious fruits: martyrdom of the self and victory in battle, as mentioned in the Quran (9:52). This is a mark of the collective identity of self-sacrifice and "martyrdom" whereby the local community as well as the ummah benefits and reaps the rewards of martyrdom.

I subscribe to the view that stresses the individually driven nature of suicide bombers arguing that they "can be educated and uneducated; religious and secular; comfortably off and destitute; their link is the decision they make to transform their powerlessness into extraordinary power". ${ }^{24}$ In highlighting the long lineage between Islamic and ethno-national resistance, I have argued that martyrdom operations - whether carried out by Islamist or resistance movementsare altruistic, self-sacrificial operations conveyed in the form of symbolic capital (honor and dignity). This generalization seems to be warranted by a correspondence among the various discourses discussed above. I suggest that the common ground for both Islamist and nationalistic-secular movements is the agreement that living under occupation is tantamount to disgrace and humiliation. As such it is respectively a religious and nationalistic duty to end the occupation using all possible means, including suicide operations.

In this article, I intended to express how both parties furnished a religious or secular political discourse to justify suicide operations. The icon that both parties, secularists and Islamists, embraced is that martyrdom operations were conducted in order to uphold the honor, pride, and dignity of the 'nation;' this being the main cause or motivation behind self-sacrifice operations. This value-laden expression of symbolic capital connotes different meanings of the word 'ummah' to the various adherents. Thus, for Saad Ghorayeb Amal ${ }^{29}$ and the Palestinians, the ummah denotes the Islamic ummah; for the SSNP the ummah refers to the 'Syrian Nation;' for the LCP the ummah pinpoints to all the destitute, the deprived in the world; for the LTTE the ummah corresponds to the Tamil nation; and for the PKK the ummah refers to a free, united, and independent Kurdistan. The common denominator among all of these conceptions of nationhood or ummah is that they are "imagined communities". ${ }^{56}$ As such, there seem to be elements pointing to pedagogy of martyrdom, the common denominator of which are symbolic and religious capital, on the one hand, and agency, on the other. Agency is salient in the rule of thumb and the prima facie duty that the recourse to suicide operations is dictated by the conditions of the battlefield where conventional weapons and capabilities prove futile or inadequate in facing a superior enemy that outguns and overpowers them. Moreover, the suicide bomber feels that she is in control since that person determines the time and place of the operation, as such exercising empowerment.

\section{Acknowledgements}

None.

\section{Conflict of interest}

The author declares no conflict of interest.

\section{References}

1. Van Henten, Jan Willem. Martyrdom, Jesus Passion and Barbarism. Biblical Interpretation. 2009;17:26.

2. Bourdieu P. The Field of cultural production. UK: Polity Press; 1993. $28 \mathrm{p}$.

3. Bourdieu P. In other words: essays towards a reflexive sociology. UK: Polity Press; 1990.

4. Kane Ousmane. Muslim modernity in postcolonial Nigeria: a study of the Society for the Removal of Innovation and Reinstatement of Tradition. Netherlands: Brill; 2003. 284 p

5. Bourdieu P. "Genèse et structure du champ religieux." Revue française de sociologie. 1971;12:295-334.

6. Bourdieu P. "Genesis and structure of the religious field." Comparative Social Research. 1991;13:1-44.

7. Ulama. Jihadi issues and the judgment of martyrdom operations. Lebanon: Al Islamiyya; 2002.

8. Khosrokhavar Farhad. Islamism and death: the revolutionary martyrs in Iran. France: Harmattan; 1995.

9. Khosrokhavar Farhad. God's new martyrs. France : Flammarion; 2002

10. Jeffrey William L. The Business of martyrdom: the history of suicide bombing. USA: Naval Institute Press. 2012;6(3):346 p.

11. Qasim Naim. Hizbullah: the curriculum, the experience, the future. Lebanon: Dar al Hadi; 2002.

12. Muqawama Al, Wataniyya Al, Lubnaniyya AI. Martyrdom operations: documents and pictures 1982-1985. Syria; 1985.

13. Richard Antoun T. Understanding fundamentalism: Christian, Islamic, and Jewish movements. USA: Altamira Press; 2001

14. Cohn Carol. Women \& Wars. UK: Polity Press; 2013.

15. Hirst David. Beware of small states: Lebanon, battleground of the Middle East. UK: Faber and Faber Ltd; 2010.

16. Pape Robert A. Dying to win: the strategic logic of suicide terrorism. Political Psychology. 2005;28(2):262-268.

17. Jaber Hala. Hezbollah: born with a vengeance. USA: Colombia University Press; 1997. 288 p.

18. Davis Joyce M. Martyrs: innocence, vengeance and despair in the Middle East. USA: Palgrave Macmillan; 2003. 214 p.

19. Ajami Fouad. The vanished Imam: Musa al Sadr and the Shia of Lebanon. USA: Cornell University Press; 1986.

20. Anon. Lanterns of victory: the stories of the martyrs of the Islamic Resistance. Lebanon: Dar al-Amir; 2001.

21. Fadlallah Ayatullah. Islam and the logic of power. 3rd ed. Lebanon: Dar alMalak; 1985

22. Fadlallah Hasan. The Collapse of the illusion: the defeat of the occupier and the victory of the Resistance in Lebanon. Lebanon: Dar al Hadi; 2001. 
23. Victor Barbara. Army of roses: inside the world of Palestinian women suicide bombers. USA: Rodale Press; 2003. 321 p.

24. Reuter Christoph. My Life as a weapon: a modern history of suicide bombing: Translated from German. USA: Princeton University Press; 2004. 18 p.

25. Lankfor Adam. The Myth of martyrdom: what really drives suicide bombers, rampage shooters, and other self-destructive killers. USA: Palgrave Macmillian; 2013. 52(3):342-343.

26. Mousawi Ibrahim. Fadlallah explains religious basis for suicide attacks. UK: Daily Star; 2002.

27. Joseph Alagha. Hizbullah's DNA and the Arab Spring. India: Knowledge World Publishers; 2013.

28. Vroom Hendrik M. Islam's adaptation to the West: on the deconstruction and reconstruction of religion. In Scottish Journal of Theology. 2007;60(2):226-241.

29. Saad Ghorayeb Amal. Hizbullah: politics and religion. UK: Pluto Press; 2002. 264 p.

30. Khalili Laleh. Heroes and martyrs of Palestine. UK: Cambridge University Press; 2007. 274 p.

31. Hamden Raymond H. Unresolved trauma and the thirst for revenge: the retribution terrorist. In: James JF, editor. The Making of a Terrorist. USA; 2006. $178 \mathrm{p}$.

32. Khaminai Al, Imam Al. The Perfume of martyrdom. Lebanon: Al Dar al Islamiyyah; 2001.

33. Gunaratna Rohan. Suicide Terrorism: A Global Threat in Terrorism in Perspective. Pamela Griset, Sue Mahan, editors. London, UK; 2003. 226 p.

34. Martin Gus. Understanding terrorism: challenges, perspectives, and Issues. 5th ed. UK: Sage Publications; 2003.

35. Alison Miranda H. Women and political violence: Female combatants in ethno-national conflict. UK: Routledge; 2009.

36. Mazurana Dyan. Women, girls, and non-state armed opposition groups. In: Carol Cohn, editor. Women \& Wars. UK: Polity Press; 2013. p. 146168 .

37. Singer PW. The New children of terror. In: James Forest, editor. The Making of a terrorist, Recruitment. UK: Praeger Security International; 2006

38. Dolnik Adam. "Learning to die: suicide terrorism in the $21^{\text {st }}$ century." In: James JF, editor. The Making of a Terrorist. USA: Praeger Security International; 2006. $171 \mathrm{p}$.
39. Bloom Mia. "Mother. Daughter. Sister. Bomber." Bulletin of Atomic Scientists. 2005;61(6):54-62.

40. Bloom Mia. Bombshell: The many faces of women terrorists. UK: Hurst \& Company; 2011

41. Cockburn Patrick. The rise of Islamic State: ISIS and the new Sunni revolution. UK: Verso; 2015.

42. Beauchamp Tom L. Philosophical ethics: an introduction to moral philosophy. 2nd ed. USA: Mc Graw Hill; 1991.

43. Cole Juan, Nikki Keddie. Shi ism and Social Protest. USA: Yale University Press; 1986.

44. Cragin Kim, Sara Daly. Women as terrorists: mothers, recruiters, and martyrs. USA: Praeger Security International; 2009. 142 p.

45. El Haddad Leila. Gaza mom: abridged version. USA: Just World Books; 2015.

46. Hasso Frances. Resistance, Repression, and Gender Politics in Occupied Palestine and Jordan. Feminist Review. 2005;96(1):11-15.

47. Kramer Martin. Sacrifice and 'Self-Martyrdom' in Shi'ite Lebanon. In: Brunswick NJ, editor. Arab Awakening and Islamic Revival. 2009;3(3):30-47.

48. Momen Moojan. The Phenomenon of religion: a thematic approach. UK: One World Publications, Oxford; 1999. 626 p.

49. Moussalli Ahmad. Historical dictionary of islamic fundamentalist movements in the Arab World, Iran, and Turkey. UK: The Scarecrow Press; 1999. 430 p.

50. Mustapha Amin. The Resistance in Lebanon: 1948-2000. Lebanon: Dar al-Hadi; 2003.

51. Schweitzer Yoran. Female suicide terrorists. Jaffe Center for Strategic Studies. Israel; 2003. 246 p.

52. Shalhoub Kevorkian Nadera. Militarization and violence against women in conflict zones in the Middle East: a Palestinian case study. UK: Cambridge University Press; 2009. 7(1):120-123.

53. Singer Peter. Practical ethics. 2nd ed. UK: Cambridge University Press 1999. $206 \mathrm{p}$

54. Wensinck AJ. The Oriental Doctrine of the Martyrs. Afdeeling Letterkunde. 1922;53(6):147-174.

55. Yamak Labib Z. The Syrian Social Nationalist Party: an ideological analysis. Center for Middle Eastern Studies. USA: Harvard; 1966. 177 p.

56. Benedict Anderson. Imagined communities: Reflections on the origin and spread of nationalism. UK: Verso; 2006. 